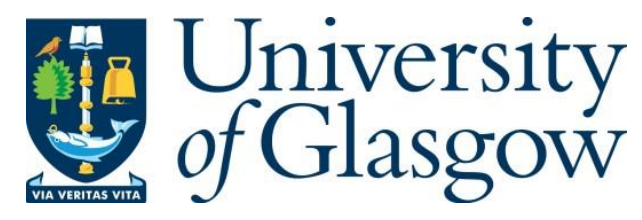

Adams, D. and Watkins, C. (2018) Making the economic case for planning. Town Planning Review, 89(5), pp. 437-442. (doi: 10.3828/tpr.2018.28)

There may be differences between this version and the published version. You are advised to consult the publisher's version if you wish to cite from it.

\title{
http://eprints.gla.ac.uk/138584/
}

Deposited on 21 March 2017

Enlighten - Research publications by members of the University of Glasgow http://eprints.gla.ac.uk 


\section{MAKING THE ECONOMIC CASE FOR PLANNING}

David Adams (University of Glasgow) and Craig Watkins (University of Sheffield)

For almost four decades, professional planners in the UK have experienced a sustained political attack on their endeavours, primarily but not exclusively from a right-wing direction. The essence of this attack is that planning serves to undermine and restrict economic growth and prosperity. One of the earliest claims was made by Michael Heseltine in 1979 and repeated by him more than thirty years later when he wrote that: "Nowhere else can the pedestrian speed of decision making in this country - and its effects - be more damaging than in planning. There are countless jobs tied up in the filing cabinets of the planning machine" (Heseltine, 2012: 110). This sentiment was subsequently echoed by the UK Government in its 2015 productivity plan entitled Fixing the Foundations which it suggested would address "particular challenges in the form of a planning system regarded by many as one of the most significant constraints facing the economy, bringing delay and inflexibility" (HM Treasury, 2015: 41).

If such attacks were motivated entirely by political hostility to the concept of planning, they might be more readily dismissed. But over the past two decades, some highly-respected urban and housing economists have been working away to establish what they see as the costs of planning intervention. Numerous peer-reviewed papers on the costs of planning have now been published in many leading journals, looking not simply as the UK but at other jurisdictions such as Hong Kong and the USA. Arguably, the most high-profile academic team to have concentrated in depth on the costs of planning is that led by Professor Paul Cheshire at the London School of Economics. In an important 2012 summary of their case, this team contended that: "Specifically, there is evidence that the UK planning system: increases house prices and reduces housing quality (with a regressive impact on low to middle income families), increases housing market volatility, increases office rents, lowers retail productivity, lowers employment in small independent retailers, (and) may not properly assess the true social costs of brownfield versus greenfield development" (Cheshire et al, 2012: abstract).

These are serious charges indeed, especially since such academic critiques of planning feed off, and feed into, evident political hostility. Surprisingly, however, until recently neither the planning profession nor the planning academy did much to counter these claims. In a phrase coined by Campbell (2008), this put both in the dangerous position of 'leaving economics to 
economists.' Of course, few planning academics or indeed planning practitioners come from an economics background, with the result that most debates in planning theory are dominated by sociological or governance perspectives, and engage very little with concerns around the costs and benefits of planning. It is therefore much to the credit of the Royal Town Planning Institute, as both a professional body and a learned society, that it has recently been at the forefront of encouraging a new programme of research into the value of planning, to which we and others have contributed (see Adams and Watkins, 2014; Adams et al., 2016, Lord et al., 2015, Wu et al., 2015).

As a first step to providing a more balanced account of the costs and benefits of planning, this initial work will hopefully encourage much greater curiosity and pluralist empirical enquiry from social science academics about the case for planning and its wider economic and social ramifications. Such research may well be essential if planning is to survive professionally (and maybe even academically) in the UK since without the necessary intellectual framework, it becomes much harder to resist political attacks on the validity of planning. In the remainder of this note, we therefore summarise the thinking around planning, markets and economics that we developed in the RTPI work and which we hope will encourage further intellectual creativity in identifying the value generated by planning.

Since value is a multi-dimensional concept, it is important neither to restrict the value of planning to economic and financial factors, nor exclude them from analysis. Drawing on Macmillan (2006), we might expect planning at its most effective to enhance some combination of exchange, use, social, environmental, image and cultural value. Conversely, when at its least effective, planning may well detract from such values. While the first two of these types of value are clearly economic in nature, we do not consider the other four to be necessarily nonfinancial, nor do we see any dichotomy between economic value and other types of value. We make this point because we do not concur with the view that recent research into the value of planning is over-focused on the economic to the detriment of other types of value (Davoudi, 2016). Rather, the kind of places where people really want to live, work and invest create all kinds of value which often find expression in economic terms. However, we certainly do not take an uncritical view of economic growth. Instead, we see long-term sustainable economic growth as more likely to result from planned interventions than from their absence. 
As well as opening up what is meant by concepts such as 'value' and 'growth', it is essential to challenge the narrowness of economic analysis that deliberately restricts planning to a particular type of development regulation. This restrictive approach is the first key weakness of the arguments deployed by Paul Cheshire and colleagues, which sets up the 'straw man' of planning as merely some kind of regulatory mechanism to determine whether particular development proposals should be approved or not, before proceeding to the relatively easy task of then knocking it down. Planning is much more complex than the simple model adopted by Cheshire et al., and it behoves all those who wish to undertake serious economic analysis of its costs and benefits, to reflect this. Our approach has been to think conceptually about the interaction between planning and real estate markets and to develop a conceptualisation that includes not only market regulation, but also market shaping, market stimulus and capacitybuilding as essential elements of planning (see Adams and Tiesdell, 2013, for a fuller discussion of each of categories). Any rounded economic analysis of the impact of planning must therefore extend to shaping instruments, such as strategic plans, and stimulus instruments, such as town centre management, and should not simply concentrate analytical attention on regulatory instruments such as development control.

The second key weakness of the approach taken by Paul Cheshire and colleagues ironically lies in their very narrow view of economics itself. In our research, we compare five different philosophical perspectives in economics, all of which have potential to enlighten our understanding of the relationship between planning and real estate markets. Most of the analytical work on the economic costs of planning, including that by the Cheshire team is set the first of these - the neo-classical perspective, which essentially explores how far planning directly affects the overall quantity of market supply, demand and price. Even here, attention has been over-concentrated on the supply side to the relative neglect of the demand side. Crucially, it is important to acknowledge the planning interventions may boost demand, rather than simply restrict supply (see Jackson and Watkins, 2011). For example, if house buyers are interested not simply in the qualities of the house itself but in those of the neighbourhood in which the house is located, then it becomes much it becomes much too simplistic to see house price rises simply as the costs of planning since they may equally reflect higher demand in well-planned areas.

This essential requirement to develop a more mature understanding of the value of planning from within the neo-classical perspective is matched by an urgent need to branch out into at 
least four other important economic perspectives. So drawing on welfare economics, for example, we might ask how far planning can overcome market failure. Here, a substantial body of work grounded in welfare economics has long explained how planning can improve economic efficiency by tackling market failure in land and property (see, for example, Evans, 2004; Klosterman, 1985). Moving on to new institutional economics, we might ask how far planning reduces or, indeed, increases, market transaction costs. Here, Webster and Lai (2003) contrast markets as institutions that potentially reduce individual transaction costs with government policies and regulations that potentially reduce collective transaction costs.

From a behavioural economics perspective, we might ask how far planning can nudge markets towards more beneficial outcomes. In this context, development plans and development control processes may actually be quite efficient in signalling potential outcomes to market participants. Their behavioural effect might indeed be positive as well as negative, creating anchors that encourage greater interest among developers in potential opportunities as well as deterring wasted expenditure in pursuing projects unlikely to meet with approval (Ferrari et al, 2011). If the case for democratic management of land use is accepted in principle, then it can be argued that an effective planning system conserves economic resources by advance signalling of likely outcomes.

Increasingly, drawing on the social construction of markets, we might ask also how far planning can transform market cultures and practices. For example, in many regeneration areas, planning has long been at the forefront of what Healey (1992) describes as the activity of 'creating markets' through strategic development or regeneration frameworks that use publicsector vision and investment to rescue weak local property markets, so breeding confidence and co-ordination among private landowners and developers. One of the main limitations of econometric forms of analysis that reduce planning to development regulation in order to measure just its costs is that they fail to pick up on this broader activity and thus seem unable to acknowledge some of the real benefits of planning. It is scant defence to argue that much of this activity falls beyond whatever constitutes the currently statutory or legal definition of planning when conceptually market stimulus is as much part of planning activity as market regulation or market shaping.

Once we recognise the breadth and scope of economic analysis, it becomes striking how narrowly based are the particular economic critiques of planning that seem to have been unduly 
influential among right-wing politicians. Yet, even within their neo-classical framework, Cheshire et al. are unduly dependent on the theory of perfect competition which has little in common with the reality of the land and housing markets in which they most interested. This is the third key weakness of their approach and is particularly strange since those now at the forefront of neo-classical analysis increasingly regard the conditions of perfect competition as a benchmark against which departures can be measured, rather than an essential prerequisite of analysis.

Take, for example, the structure and behaviour of the UK housebuilding industry, dominated as it is by relatively few large firms, which ensures that monopolistic not perfect competition exists in housebuilding. As recent research has thus clearly shown (Archer and Cole, 2016), in markets where demand is rising and there is upward pressure on prices, volume housebuilders will prioritise profit growth above volume growth. Alongside well-known skills and capacity constraints in the housebuilding sector, this makes it naïve to attribute all supply constraints to the planning system. Yet, most mainstream models do exactly this, making little effort to take account of market structure or capacity constraints attributable to labour and skills shortages. This technical weakness means that their supply equations are often under-specified and fail to capture negative impacts associated with a host of unmeasured constraints. In short, some of the costs they blame on the planning system arise elsewhere.

While Cheshire et al. (2012: 4) claim that their approach represents "a considerable underestimate of the true costs of planning" the theoretical and methodological weaknesses inherent in their analysis probably mean that, in our view, the reverse is more likely to be true. Despite this, the hard numbers generated by such work seem to captivate political attention and attract popular headlines, irrespective of any conceptual or technical limits to the analysis. Planning must now work hard to create an alternative economic discourse, drawing on the fuller range of economic perspectives, which accurately demonstrates the added value of planned intervention in real estate market.

The theory of collective action can provide an important theoretical foundation here since it focuses on whether and how the whole exceeds the value of the sum of the parts. In this context, an important component of the economic case for planning derives from its potential to produce complex but integrated forms of development, where otherwise disintegration might be rife between one site and next, between the public and private realms, between the additional 
infrastructure requirements generated by development and their actual provision, and crucially between the present and future. In short, it is quite possible to articulate a strong theoretical case that the economic benefits of planning are likely to exceed its costs, but we need a lot more detailed research to substantiate this claim with hard evidence (Adams et al, 2016). This must be an important task for the planning academy in the years to come. And the results may cause us to reflect on what style of planning is most likely to generate those benefits and thus influence practice accordingly.

\section{REFERENCES}

Adams, D. and Tiesdell, S. (2013) Shaping Places: Urban Planning, Design and Development, London: Routledge.

Adams, D. and Watkins, C. (2014) The Value of Planning, London: Royal Town Planning Institute.

Adams, D., O'Sullivan, M., Inch, A., Tait, M., Watkins, C. and Harris. M. (2016) Delivering the Value of Planning, London, Royal Town Planning Institute.

Archer, T. and Cole, I. (2016) Profits before Volume: Major Housebuilders and the Crisis of Housing Supply, Sheffield: Centre for Regional Economic and Social Research, Sheffield Hallam University.

Campbell, H. (2008) Middle-class places... and the dangers of leaving economics to economists, Planning Theory \& Practice, 9.1, 3-6.

Cheshire, P., Leunig, T., Nathan, M. and Overman, H. (2012) Links between Planning and Economic Performance: Evidence Note for the LSE Growth Commission, London: London School of Economics.

Davoudi, S. (2016) Viewpoint: The value of planning and the values in planning, Town Planning Review, 87.6, 615-618.

Evans, A. W. (2004) Economics and Land Use Planning, Oxford: Blackwell.

Ferrari, E., Henneberry, J., Leahy Laughlin, D., Tait, M., Watkins, C. and McMaster, R. (2011) Behavioural Change Approach and the Housing Sector: A Scoping Study, London: UK Department for Communities and Local Government.

Healey, P. (1992) The reorganisation of the state and the market in planning, Urban Studies, 29, 411-434.

Heseltine, M. (2012) No Stone Unturned: In Pursuit of Growth, London: UK Department for Business, Innovation and Skills. 
HM Treasury (2015) Fixing the Foundations: Creating a More Prosperous Nation, Cm. 9098, London: HM Treasury.

Jackson, C. and Watkins, C. (2011) Planning policy and retail property investment in the UK, Urban Studies, 48, 2321-2338.

Klosterman, R. E. (1985) Arguments for and against planning, Town Planning Review, 56: 520

Lord, A., O'Brien, P., Sykes, O., and Sturzaker, J. (2015) Planning as 'Market Maker': How Planning is used to Stimulate Development in Germany, France and the Netherlands, London: Royal Town Planning Institute.

Macmillan, S. (2006) Added value of good design, Building Research and Information, 34, 257-271.

Wu, F., Zhang, F. and Wang, Z. (2015) Planning China's Future: How Planners Contribute to Growth and Development, London: Royal Town Planning Institute.

Webster, C. and Lai, W. C. L. (2003), Property Rights, Planning and Markets: Managing Spontaneous Cities, Cheltenham: Edward Elgar. 